\title{
Dziecko wiotkie z punktu widzenia pediatry i neurologa dziecięcego
}

\author{
Floppy Child from the point of view of a pediatrician and child neurologist
}

\author{
Paulina Komasińska (D), Barbara Steinborn (iD) \\ Katedra i Klinika Neurologii Wieku Rozwojowego UM im. K. Marcinkowskiego w Poznaniu, \\ DOI:10.20966/chn.2020.59.466
}

\section{STRESZCZENIE}

Wiotkość mięśniowa to obniżony opór podczas wykonywania ruchów biernych w stawach. Prawidłowe napięcie mięśniowe jest wynikiem współdziałania struktur ośrodkowego i obwodowego układu nerwowego. Zatem zespół dziecka wiotkiego może stanowić wynik uszkodzenia górnego neuronu ruchowego - wiotkość centralna lub dolnego neuronu ruchowego - wiotkość obwodowa. Wiotkość centralna charakteryzuje się obecnością prawidłowych lub wygórowanych odruchów, prawidłową lub nieznacznie zmniejszoną siłą mięśniową, towarzyszyć jej mogą ograniczone zainteresowanie bodźcami zewnętrznymi, drgawki. Dla wiotkości obwodowej z kolei typowe są: znaczne osłabienie siły mięśniowej, arefleksja, przy prawidłowym kontakcie wzrokowym. Najczęstszą przyczynę wiotkości centralnej stanowią uszkodzenia i wady ośrodkowego układu nerwowego oraz zespoły uwarunkowane genetycznie. Pierwszy etap diagnostyki hipotonii centralnej stanowią zatem badania obrazowe glowy i/lub rdzenia kręgowego oraz badania genetyczne szczególnie, gdy współwystępują cechy dysmorficzne lub obciążenie rodzinne. $Z$ kolei do najczęstszych przyczyn hipotonii obwodowej zalicza się: rdzeniowy zanik mięśni (SMA) i choroby mięśni. Poszukiwanie przyczyn hipotonii obwodowej należy rozpocząć od wykonania badań genetycznych w kierunku SMA. Następny etap stanowi oznaczenie poziomu kinazy kreatyninowej (CK) oraz badania elektrofizjologiczne. Ostatnim etapem jest poszerzenie diagnostyki o badania inwazyjne - biopsję mięśnia czy biopsję nerwu, z których obecnie coraz częściej rezygnuje się na rzecz badań genetycznych. Jeśli u pacjenta z wiotkością współwystępuje spektrum objawów klinicznych takich jak: wymioty, zaburzenia oddychania, zaburzenia świadomości, zwyrodnienie barwnikowe siatkówki, hepatosplenomegalia, należy uwzględnić choroby metaboliczne. Natomiast jeśli stwierdza się nadmierną ruchomość w stawach przy prawidłowej sile mięśniowej konieczne jest przeprowadzenie diagnostyki w kierunku chorób tkanki łącznej. Zidentyfikowanie przyczyny hipotonii ma szczególne znacznie kliniczne, gdyż w niektórych chorobach (np. SMA, choroba Pompego) istnieją możliwości skutecznego leczenia hamującego ich postęp.

Słowa kluczowe: zespół dziecka wiotkiego, hipotonia centralna, hipotonia obwodowa, napięcie mięśniowe, wrodzone zespoły miasteniczne

\section{ABSTRACT}

Hypotonia/floppiness is a reduced resistance to passive movements in the joints. Proper muscle tone is the result of the interaction of the structures of the central and peripheral nervous systems. Thus, the floppy child syndrome may result from damage to the upper motor neuron - central hypotonia or the lower motor neuron - peripheral hypotonia. Central hypotonia is characterized by the presence of normal or excessive reflexes, normal or little reduced muscle strength, may be accompanied by limited interest in external stimuli and convulsions. For peripheral hypotonia the following are typical: significant muscle weakness, areflexia with normal eye contact. The most common causes of central hypotonia are damages and defects of the central nervous system and genetically determined syndromes. The first step in the diagnosis of central hypotonia is therefore imaging examinations of the head and / or spinal cord and genetic examinations, especially when dysmorphic features or family burden are present. In turn, the most common causes of peripheral hypotonia are spinal muscular atrophy (SMA) and muscle disease. The search for the causes of peripheral hypotonia should begin with genetic testing for SMA. The next stage is to determine the level of creatine kinase (CK) and electrophysiological tests. The last stage is the extension of diagnostics to invasive tests - muscle or nerve biopsy, which are now increasingly abandoned in favor of genetic tests. If in a patient with hypotonia coexists a spectrum of clinical symptoms such as vomiting, respiratory disorders, disturbances of consciousness, retinitis pigmentosa or hepatosplenomegaly, metabolic diseases should be taken into account. However, if there is excessive mobility in the joints with normal muscle strength, it is necessary to diagnose towards connective tissue diseases. Identifying the cause of hypotonia is of particular clinical importance, as in some diseases (eg SMA, Pompe disease) there are effective treatments that will inhibit their progress.

Key words: floppy child syndrome, central hypotonia, peripheral hypotonia, muscle tone, congenital myasthenic syndromes.

\section{WSTĘP}

Wiotkość mięśniowa (hipotonia) to obniżony opór podczas wykonywania biernych ruchów w stawach, który może przebiegać z osłabieniem siły mięśniowej oraz zwiększonym zakresem ruchomości w stawach. Na regulację napięcia mięśniowego wpływa współdziałanie wielu struktur ośrodkowego jak i obwodowego układu nerwowego. Hipotonia może być zatem objawem dys- funkcji móżdżku, uszkodzenia rogów przednich, korzeni rdzeniowych, nerwów obwodowych, złącza nerwowomięśniowego oraz mięśni. Prawidłowo napięcie mięśniowe jest zdeterminowane również przez właściwości ścięgien, powięzi i struktur stawowych, dlatego choroby tkanki łącznej należy uwzględnić również $\mathrm{w}$ analizie przyczyn hipotonii. Obniżone napięcie mięśniowe jest elementem 
obrazu klinicznego zaburzeń metabolicznych, zespołów genetycznych jak i uogólnionych infekcji [1].

Jednak lista potencjalnych przyczyn hipotonii wraz z postępem rozwoju badań genetycznych ulega systematycznemu wydłużaniu. Wobec pojawiających się nowych możliwości leczenia przyczynowego ustalenie etiopatogenezy hipotonii powinno być priorytetem dla lekarzy wszystkich specjalności zajmujących się dziećmi. Jednak różnorodność czynników ją wywołujących implikuje trudności w postępowaniu diagnostycznym i powoduje, że staje się ono wyzwaniem zarówno dla pediatrów jak i neurologów dziecięcych, dlatego też w poniższej publikacji zostaną omówione przyczyny oraz zasady diagnostyki dziecka z obniżonym napięciem mięśniowym.

\section{Zespół dziecka wiotkiego - wywiad}

Postępowanie diagnostyczne z pacjentem wiotkim należy rozpocząć od szczegółowego zebrania wywiadu.

Hipotonia mięśniowa na ogół ujawnia się w pierwszych miesiącach życia dziecka, jednak często dane z wywiadu położniczego wskazują na występowanie wiotkości już w okresie płodowym. Do obrazu klinicznego związanego z obniżeniem napięcia mięśniowego w okresie prenatalnym należą: słabe, rzadko wyczuwalne ruchy płodu, jego nieprawidłowe ułożenie czy wielowodzie. Czas trwania porodu bywa przedłużony, a jego przebieg powikłany wystąpieniem urazu okołoporodowego. Noworodek rodzi się często przedwcześnie, uzyskuje na ogół niską punktację w skali Apgar (obniżone napięcie mięśniowe, brak odruchów obronnych, obecność wysiłku oddechowego), wymaga wentylacji mechanicznej oraz karmienia za pomocą zgłębnika żołądkowo-jelitowego. Jeśli hipotonia ma pochodzenie ośrodkowe towarzyszyć jej mogą: drgawki, zaburzenia świadomości, nieprawidłowe ruchy gałek ocznych. Z obniżeniem napięcia mięśniowego może wiązać się późniejsze nabywanie przez dziecko kamieni milowych oraz nieprawidłowy wzorzec chodu. W przypadkach uwarunkowanych genetycznie chorób hipotonia może występować u innych członków rodziny, dlatego też trzeba uwzględnić dane dotyczące poronień, przedwczesnych zgonów, zaburzeń chodu i opóźnienia rozwoju psychoruchowego występującego $\mathrm{W}$ rodzinie $[1,2]$.

\section{Zespół dziecka wiotkiego - badanie przedmiotowe}

Kolejnym krokiem w analizie przyczyn wiotkości jest badanie przedmiotowe, w którym należy zwrócić szczególną uwagę na występowanie: cech dysmorfii (np. długogłowie, migdałowate szpary powiekowe, które są charakterystyczne dla zespołu Pradera-Williego, a wydatne czoło i szerokie ciemię dla zespołu Zellwegera), powiększenia narządów jamy brzusznej (hepatosplenomegalia w chorobach spichrzeniowych, zakażeniach z grupy TORCH, adrenoleukodystrofii niemowlęcej), zwichnięć stawów biodrowych czy artrogrypozy wynikających z unieruchomienia płodu w jamie macicy. Do innych cech wskazujących na pochodzenie hipotonii należą: powiększenie języka w chorobie Pompego, fascykulacje języka w uszkodzeniu rogów przednich rdzenia kręgowego. Ponadto nadmierna ruchomość w stawach, hiperelastyczna skóra oraz niebieskie zabarwienie twardówek mogą sugerować rozpoznanie chorób tkanki łącznej [1].

Następny etap stanowi ocena pozycji dziecka w supinacji. Cechą wspólną niezależnie od etiologii i lokalizacji uszkodzenia jest ułożenie w ,pozycji żaby” (ang. frog -like posture)- z odwiedzeniem i rotacją na zewnątrz kończyn dolnych oraz wyprostem lub zgięciem kończyn górnych.

Jako, że ocena napięcia mięśniowego w czasie ruchów biernych ma charakter subiektywny, w praktyce klinicznej do potwierdzenia obniżonego napięcia mięśni szyi, grzbietu oraz obręczy barkowej stosuje się próbę trakcji, w której dziecko pociągane jest za nadgarstki z pozycji supinacyjnej do siedzącej- zdrowe niemowlę utrzymuje głowę w linii pośrodkowej, natomiast u niemowlęcia hipotonicznego głowa opadu ku tyłowi. Innym objawem związanym z obniżeniem napięcia mięśniowego w obręczy barkowej jest objaw „wyślizgujących się barków”- dziecko badane w podwieszeniu wertykalnym wyślizguje się z rąk badającego, a jego głowa opada. Z kolei w podwieszeniu poziomym pacjent układa się w pozycji odwróconej litery U- głowa opada, tułów tworzy łuk, a kończyny bezwładnie zwisają- dziecko ,przelewa” się przez ręce badającego.

$\mathrm{U}$ pacjenta $\mathrm{z}$ wiotkością leżącego na plecach łokieć kończyny górnej przeciągniętej w poprzek klatki piersiowej znajduje się poza linią środkową ciała (próba szarfy, objaw szala) [2-4].

Hipotonii mięśniowej może towarzyszyć osłabienie siły mięśniowej. Osłabienie siły mięśniowej przejawia się jako ograniczona motoryka spontaniczna, osłabione ssanie, cichy płacz, uboga mimika twarzy, nieprawidłowy tor oddychania. Odruchy ścięgniste mogą być wygórowane, prawidłowe, osłabione lub nieobecne [1-4].

Przed przystąpieniem do dalszych etapów procesu diagnostycznego należy wykluczyć stany zagrażające życiu takie jak: uogólnione infekcje, neuroinfekcje, hipoglikemię, dyselektrolitemie zatrucia lekami czy narkotykami (w przypadku ich stosowania przez matki noworodków) jako przyczyny hipotonii.

\section{Zespół dziecka wiotkiego - wiotkość centralna versus obwodowa}

$\mathrm{Na}$ podstawie badania przedmiotowego wiotkość można zróżnicować na wiotkość centralną (związaną $\mathrm{z}$ uszkodzeniem górnego neuronu ruchowego) oraz obwodową (wynikającą ze zmian zlokalizowanych w rogach przednich rdzenia kręgowego, nerwach obwodowych, połączeniu nerwowo-mięśniowym, mięśniach). Poza lokalizacją uszkodzenia te dwie postaci odróżnia rozkład obniżonego napięcia, w hipotonii centralnej dominuje zajęcie mięśni osiowych nad mięśniami kończyn, w obwodowej ma charakter globalny, obejmuje również mięśnie kończyn.

Hipotonię obwodową charakteryzuje znaczne osłabienie siły mięśniowej w przeciwieństwie do, hipotonii centralnej, gdzie siła mięśniowa jest prawidłowa lub jedynie nieznacznie osłabiona. Odruchy ścięgniste w hipotonii centralnej są wygórowane, a nawet polikloniczne, natomiast w hipotonii obwodowej są osłabione lub nieobecne. 
Dla dziecka z wiotkością pochodzenia centralnego typowa jest obecność towarzyszących zaburzeń świadomości, drgawek, nieprawidłowego rozwoju umiejętności społecznych, które nie występują u pacjentów z wiotkością o obwodowym charakterze.

Twarz miopatyczna ze stale otwartymi ustami, ubogą mimiką, ptozą czy oftalmoplegią stanowi natomiast element obrazu klinicznego hipotonii obwodowej.

Należy pamiętać, że istnieją również jednostki, w których cechy wiotkości obwodowej i centralnej mogą się nakładać (leukodystrofie) oraz takie, których nie można przyporządkować do żadnej z wymienionych grup. Jeśli obniżonemu napięciu mięśniowemu towarzyszą inne objawy W postaci: hepatosplenomegalii, wielotorbielowatości nerek, jaskry, zaćmy, zwyrodnienia barwnikowego siatkówki, dysmorfii twarzy, wad kończyn, szczególnego zapachu dziecka i jego wydalin to wiotkość ta należy do tzw. hipotonii plus, która wymaga wielokierunkowej diagnostyki omówionej szczegółowo poniżej [1, 2, 4-6].

\section{Zespół dziecka wiotkiego z hipotonią centralną - postępowanie diagnostyczne}

Wiotkość pochodzenia centralnego występuje znacznie częściej niż hipotonia obwodowa. W pracy Laugela i wsp. [7], w której przeanalizowano 144 przypadki wiotkości w okresie niemowlęcym, hipotonię o charakterze centralnym stwierdzono aż u 98 pacjentów. Warto zauważyć, że w grupie pacjentów z wiotkością centralną napięcie mięśniowe w trakcie obserwacji ulega poprawie a nawet, w niektórych przypadkach progresji do wzmożonego napięcia, co może komplikować proces diagnostyczny.

Do jej głównych przyczyn należą uszkodzenia ośrodkowego układu nerwowego takie jak encefalopatia niedotlenieniowo-niedokrwienna, krwotoki wewnątrzczaszkowe, wady wrodzone, urazy czy wady rdzenia kręgowego oraz zespoły genetyczne.

Z tych względów postępowanie diagnostyczne powinno rozpocząć się od wykonania badań neuroobrazowych oraz diagnostyki genetycznej. Badanie tomografii komputerowej (KT) pozwala na uwidocznienie wewnątrzczaszkowych zwapnień, które są cechą charakterystyczną dla zespołu Aicardiego-Goutieresa i dla cytomegalii wrodzonej. Badania rezonansu magnetycznego (MR) natomiast jest szczególnie przydatne w identyfikacji wad strukturalnych mózgowia, rdzenia kręgowego oraz zmian w przebiegu encefalopatii niedotlenieniowo-niedokrwiennej i chorób metabolicznych. Spośród wad strukturalnych do najczęściej identyfikowanych należą: zaburzenia migracji neuronalnej prowadzące do pogrubienia kory mózgowej z pachy i polimikrogyrią, agenezja ciała modzelowatego, holoprosencephalia, poszerzenie komór mózgu, wady pnia mózgu, anomalie budowy móżdżku- zespół Joubert, hipoplazja mostowo-móżdżkowa. Dla encefalopatii metabolicznych w obrazowaniu charakterystyczne są zmiany sygnału z istoty białej, zajęcie jąder podstawy oraz podkorowych włókien $\mathrm{U}$ [1, 3-5].

Obraz wiotkiego dziecka można spotkać również w przypadku wad dysraficznych czy syryngomielii rdzenia kręgowego. Do nieprawidłowości sugerujących te rozpoznania należą występowanie: skrzywienia bocznego kręgosłupa, kępki włosów w okolicy lędźwiowo-krzyżowej kręgosłupa, dysfunkcji zwieraczy oraz w zależności od poziomu uszkodzenia wygórowanych lub zniesionych odruchów głębokich.

Wiele chorób uwarunkowanych genetycznie może w swoim obrazie klinicznym zawierać wiotkość, której towarzyszą na ogół wady budowy czaszki, kończyn oraz narządów wewnętrznych często sugerujące określony zespół. Do najczęstszych z nich należą zespół Downa i zespół Pradera-Williego.

Zespół Downa i wiele innych zespołów wynikających z zaburzeń liczby, struktury chromosomów może wiązać się z hipotonią w okresie niemowlęcym, dlatego też diagnostykę dziecka wiotkiego należy rozpocząć od wykonania badania kariotypu umożliwiającego detekcję aberracji liczbowych i dużych aberracji strukturalnych. Stanowi ono podstawowe badanie u dzieci z hipotonią, której towarzyszą opóźnienie rozwoju psychoruchowego, cechy dysmorfii czy zespół wad. O ile rozpoznanie zespołu Downa nie nastręcza trudności, o tyle zespół Pradera-Williego może zostać błędnie rozpoznany w pierwszych miesiącach życia dziecka jako schorzenie z kręgu chorób nerwowo-mięśniowych. Niemowlęta $z$ tym zespołem od urodzenia prezentują głęboką hipotonię, bardzo słaby odruch ssania (często wymagają żywienia za pomocą zgłębnika nosowo-żołądkowego), cichy płacz, brak odruchów (pomimo centralnego pochodzenia wiotkości), ale przy zachowanych ruchach spontanicznych kończyn. Ich rozwój psychoruchowy jest opóźniony. Cechy dysmorfii w postaci dolichocefalii, migdałowatych szpar powiekowych, trójkątnych ust stają się wyraźnie widoczne około 5/6. m.ż. W drugim półroczu życia stan dzieci z zespołem Pradera-Williego poprawia się, jedzą chętniej, z czasem spożywają ilości istotnie większe niż zapotrzebowanie kaloryczne, są bardziej ruchliwe, nawiązują kontakt $\mathrm{z}$ otoczeniem, hipotonia zaczyna ustępować. Powyżej 3 r.ż ujawniają się wszystkie charakterystyczne cechy zespołu z wiodącą otyłością centralną, niepełnosprawnością intelektualną, hipoplastycznymi narządami płciowymi- małym penisem, hipoplazją moszny, wnętrostwem u chłopców oraz małą łechtaczką u dziewczynek. Przyczynę zespołu stanowi delecja genów w regionie 15 q11.3 na chromosomie ojcowskim, rzadziej jednorodzicielska matczyna disomia, wyjątkowo rzadko (w 1\% przypadków) defekt piętnowania powodujący nieprawidłową ekspresję genów z chromosomu ojcowskiego mimo ich obecności.

Test metylacyjny pozostaje badaniem pierwszego wyboru przy podejrzeniu tego zespołu, w przypadku jego nieprawidłowego wyniku, który wskazuje na brak ojcowskiej kopii regionu 15q11.3, kontynuuje się badania w celu wykluczenia disomii jednorodzicielskiej.

Także aberracje dotyczące subtelomerowych regionów chromosomów stanowią znaczącą przyczynę zaburzeń rozwoju, obniżonego napięcia mięśniowego i niepełnosprawności intelektualnej. Do ich wykrywania służą techniki cytogenetyki molekularnej takie jak fluorescencyjna 
hybrydyzacja in situ (ang. Fluorescent in situ Hybridization) - FISH.

Hipotonia stanowi także element obrazu klinicznego zespołów mikrodelecyjnych takich jak: zespół Angelmana, Smitha-Magenisa czy Williamsa. Jedną z nowoczesnych technik cytogenetyki molekularnej, która służy m.in. do wykrywania submikroskopowym zmian chromosomów (mikrodelecji i mikroduplikacji) stanowi porównawcza hybrydyzacja genomowa do mikromacierzy (aCGH).

W przypadku chorób wywołanych mutacją pojedynczych genów (zespół FraX, zespół Lowe’a, zespół Smith-Lemli-Opitz) pomocne są metody biologii molekularnej. Jeśli choroba spowodowana jest mutacjami zawsze w tym samym genie, wówczas podstawową metodą diagnostyki jest PCR (ang. Polymerase Chain Reaction). Natomiast W diagnostyce chorób jednogenowych o heterogennym podłożu można zastosować mikromacierze SNP (ang. Single Nucleotide Polymorphism), które pozwalają na zidentyfikowanie dużej liczby mutacji w wielu genach jednocześnie, ograniczeniem metody jest to, że wykrywa tylko znane mutacje. W przypadkach gdy podłoże genetyczne danej choroby jest nieznane przydatne okazują się metody WES (ang. Whole Exome Sequencing-sekwencjonowanie całego eksonu) lub WGS (ang. Whole Genome Sequencing)- sekwencjonowanie całego genomu) [3].

\section{Zespół dziecka wiotkiego z hipotonią obwodową - postępowanie diagnostyczne}

Hipotonia obwodowa stanowi element chorób związanych z uszkodzeniem rogów przednich rdzenia kręgowego, nerwów obwodowych, mięśni oraz zaburzeń transmisji nerwowo-mięśniowej.

W chorobie związanej z uszkodzeniem motoneuronów charakterystyczna jest uogólniona wiotkość z uogólnionym osłabieniem mięśni, z zaoszczędzeniem przepony, mięśni twarzy oraz zwieraczy.

W neuropatiach obwodowych dominuje zajęcie mięśni dystalnych części kończyn z ich zanikiem.

W zaburzeniach transmisji nerwowo-mięśniowej (zespoły miasteniczne, botulizm niemowlęcy) typowe objawy wynikają z zajęcia mięśni opuszkowych i gałkoruchowych, a w miopatiach zwykle początkowo dochodzi do zajęcia mięśni proksymalnych części kończyn, któremu mogą towarzyszyć przykurcze.

Najczęstszą przyczynę wiotkości, ujawniającej się w okresie niemowlęcym z towarzyszącym znacznym osłabieniem siły mięśniowej, ale prawidłowym kontaktem z otoczeniem, stanowi rdzeniowy zanik mięśni SMA (ang. Spinal Muscular Atrophy). Szybkie potwierdzenie rozpoznania daje obecnie możliwość zastosowania leczenia hamującego postęp choroby, dlatego też diagnostykę hipotonii należy rozpocząć od wykonania badań genetycznych. Złoty standard stanowi badanie ilościowe z równoległą oceną ilości kopii genów SMN1 i SMN2. W 95\% przypadków wykrywa się homozygotyczną delecję eksonów 7 i 8 w genie SMN1 (5q), w pozostałych obecna jest delecja w jednym genie, co implikuje konieczność poszukiwania mutacji punktowych w drugiej kopii genu SMN1. Poza klasycznym SMA, wiotkość jest również stałym elementem obrazu klinicznego rzadszych postaci SMA takich jak: przeponowa postać rdzeniowego zaniku mięśni, dziecięcy rdzeniowy zanik mięśni sprzężony z płcią, rdzeniowy zanik mięśni z hipoplazją mostowo-móżdżkową czy chorób przebiegających z fenotypem SMA-like takich jak np.: encefalopatia mitochondrialna o obrazie SMA-like [8, 9].

Postać przeponowa rdzeniowego zaniku mięśni przebiegająca z niewydolnością oddechową (ang. Spinal Muscular Atrophy respiratory distress type 1 -SMARD 1) związana z mutacjami genu IGHMBP2, dziedziczona autosomalnie recesywnie. Dominujący objaw stanowi porażenie przepony jedno- lub obustronne prowadzące do niewydolności oddechowej. Oprócz niego do obrazu klinicznego należą: cichy płacz, zaburzenia połykania, osłabienie siły mięśniowej, które początkowo dotyczy mięśni odsiebnych, następnie obejmuje pozostałe grupy mięśni i prowadzi ostatecznie do unieruchomienia. Dodatkowo obserwuje się zaburzenia autonomiczne pod postacią zaburzeń rytmu serca, nadmiernej potliwości, zaparć oraz zmniejszoną wrażliwość na ból i temperaturę.

Dziecięcy rdzeniowy zanik mięśni sprzężony z płcią (ang. X-linked infantile spinal muscular atrophy-SMAX2, XL-SMA) związany jest z mutacjami genu UBE1, dziedziczony jako cecha recesywna sprzężona z płcią. Przebiega z wrodzoną wiotkością, arefleksją, artrogrypozą oraz złamaniami kości, do których dochodzi w okresie wewnątrzmacicznym. Najgroźniejsze jego powikłanie stanowi niewydolność oddechowa, prowadzącą do zgonu około 2 r.ż.

Rdzeniowy zanik mięśni z hipoplazją mostowo-móżdżkową (ang. Spinal Muscular atrophy with pontocerebellar hipoplazja SMA-PCH) stanowi heterogenną klinicznie i genetycznie grupę chorób. W piśmiennictwie pojawiają się opisy, w których wiotkość i osłabienie siły mięśniowej występują już w okresie prenatalnym lub obecne są od urodzenia oraz inne, w których wiotkość i opóźnienie rozwoju psychoruchowego z towarzyszącymi objawami móżdżkowymi rozpoczynają się w wieku około 4-6 m.ż. Wspólną cechą są zmiany w obrębie móżdżku stwierdzane w badaniu obrazowym mające różne nasilenie od łagodnej hipoplazji po masywny zanik mostowo-móżdżkowy.

Encefalomiopatia mitochondrialna o obrazie SMA-like stanowi w zasadzie chorobę mitochondrialną związaną z mutacjami genu SCO2 i deficytem oksydazy cytochromu c. Początkowo obraz kliniczny tej choroby przypomina SMA, charakterystyczna jest znaczna wiotkość z osłabieniem odruchów, krtaniowym stridorem wdechowym, jednak w późniejszych fazach choroby różnice stają się wyraźnie widoczne. Wynikają m.in. z postępującego uszkodzenia centralnego układu nerwowego- pojawia się pogorszenie kontaktu wzrokowego, wzmożenie napięcia mięśniowego, drgawki, hipertermia ośrodkowa. Stopniowo rozwija się niewydolność oddechowa oraz u części pacjentów kardiomiopatia przerostowa. Stałym objawem jest podwyższone stężenie mleczanów we krwi, płynie mózgowo-rdzeniowym, moczu [8, 9].

W diagnostyce wiotkości o charakterze obwodowym ważną rolę odgrywają badania elektrofizjologiczne (elek- 
troneurografia-ENG, elektromiografia-EMG), które pozwalają określić lokalizację (nerw obwodowy, złącze nerwowo-mięśniowe, mięśnie) zaburzeń w obrębie dolnego neuronu ruchowego. Stwierdzenie zapisu neurogennego (prawidłowa amplituda odpowiedzi mięśniowej, fascykulacje, fibrylacje, dodatnie fale ostre) ukierunkowuje diagnostykę na SMA i neuropatie. Przy podejrzeniu SMA jak wspomniano powyżej, badanie genetyczne powinno być wykonane na pierwszym miejscu bez poprzedzających badań elektrofizjologicznych.

Neuropatie obwodowe stanowią dość rzadką przyczynę wiotkości, jednak znane są przypadki wrodzonych neuropatii ujawniających się w pierwszym półroczu życia.

W neuropatiach obwodowych demielinizacyjnych charakterystyczna jest zwolniona szybkość przewodzenia, a w aksonalnych zmniejszona amplituda odpowiedzi $\mathrm{M}$. Dziedziczne neuropatie często swoim przebiegiem klinicznym mogą przypominać SMA- dziecko prezentuje głęboką hipotonię, znaczne osłabienie mięśni zwłaszcza dystalnych części kończyn i osłabienie/brak odruchów ścięgnistych. Jednak w odróżnieniu od SMA, w niektórych neuropatiach stężenie białka w płynie mózgowo-rdzeniowym może być podwyższone. Ponadto w SMA szybkość przewodzenia jest generalnie prawidłowa i zanikiem są początkowo objęte mięśnie odsiebne.

Większość pacjentów z rozpoznanymi neuropatiami porusza się samodzielne, choć nabycie umiejętności chodzenia jest znacznie opóźnione. Z wiekiem wzrasta częstość deformacji stóp i skoliozy, jednak osłabienie siły mięśniowej $\mathrm{z}$ reguły nie postępuje.

Do neuropatii uwarunkowanych genetycznie ujawniających się w okresie niemowlęcym należą: zespół Dejerine-Sottas oraz wrodzony zespół hipomielinizacyjny (CMT4). Zespół Dejerine-Sottas stanowi dziedziczoną w sposób autosomalnie dominujący neuropatię hipomielinizacyjną związaną z mutacjami genów: PMP22, P0, EGR2. Neuropatia ta charakteryzuje się znacznie zwolnioną szybkością przewodzenia NCV( ang. Nerve Conduction Velocity) $<6$ m/s, która wynika ze znacznie zmniejszonej ilości mieliny w osłonkach nerwów obwodowych. W badaniu histopatologicznym nerwu obwodowego charakterystyczne są struktury przypominające „łuski od cebuli”. Wrodzony zespół hipomielinizacyjny przypomina zespół Dejerine-Sottas, ale jego przebieg jest cięższy, a rokowanie gorsze. Pacjenci od urodzenia prezentują osłabienie siły mięśniowej, znacznego stopnia hipotonię mięśniową oraz artrogrypozę. Dodatkowo występują zaburzenia połykania, a niewydolność oddechowa prowadzi do przedwczesnej śmierci. W badaniach elektrofizjologicznych NCV jest nieoznaczalna, a w biopsji nerwu obwodowego stwierdza się kompletny brak mieliny oraz struktur przypominających „łuski od cebuli”. Do innych neuropatii, których objawy wpisują się w zespół dziecka wiotkiego należą: niemowlęca neuroaksonalna dystrofia (choroba Seitel-Bergera), olbrzymia aksonalna neuropatia, rodzinna dysautonomia (zespół Riley-Day), leukodystrofia metachromatyczna. W leukodystrofii metachromatycznej oprócz zajęcia obwodowego układu nerwowego dochodzi również do zajęcia ośrodkowego układu nerwowego. Pacjenci do 1.-2. roku życia rozwijają się prawidłowo, następnie ujawnia się obniżone napięcie mięśniowe, arefleksja, zaburzenia chodu. Dla bardziej zaawansowanej postaci charakterystyczne jest pogorszenie czynności intelektualnych i wzmożenie napięcia mięśniowego o charakterze spastycznym. W rodzinnej dysautonomii, która jest chorobą dziedziczoną autosomalnie recesywnie, występującą głównie w populacji Żydów aszkenazyjskich hipotonii towarzyszą objawy takie jak: zmniejszone łzawienie, nadmierna potliwość, hipotensja ortostatyczna, nieprawidłowa regulacja ciśnienia tętniczego, napadowe wymioty, niewrażliwość na ból i temperaturę oraz napady padaczkowe i bezdechy [1, 6, 10-11].

Badanie elektrofizjologiczne pozwalają także na identyfikację chorób związanych z zaburzeniami transmisji nerwowo-mięśniowej, dla których charakterystyczny jest spadek amplitudy kolejnych potencjałów wywołanych bodźcami ponadmaksymalnymi o różnej częstotliwości w badaniu elektrofizjologicznym. Ważną przyczynę hipotonii ujawniającej się w okresie niemowlęcym stanowi miastenia. Dzieci z różnymi postaciami miastenii prezentują wspólne cechy, do których należą: uogólnione osłabienie mięśni narastające w czasie ich używania, osłabienie/porażenie mięśni twarzy, ptoza, trudności w karmieniu, bezdechy, zaburzenia oddychania, cichnący płacz oraz prawidłowe odruchy, co wyróżnia miastenię na tle innych przyczyn hipotonii obwodowej.

Przejściowa miastenia noworodków to choroba rozwijająca się u noworodków, których matki chorują na miastenię. W czasie ciąży przeciwciała przeciw receptorowi dla acetylocholiny obecne we krwi matki przechodzą przez łożysko. Szacuje się, że problem ten dotyczy do $12 \%$ noworodków matek z miastenią. Objawy pojawią się od razu po urodzeniu lub w pierwszych dobach życia, trwają kilka tygodni, ustępując samoistnie. W miarę obniżania miana przeciwciał poprawia się stan dziecka. Na ten typ zaburzeń miastenicznych wskazuje wywiad obciążony występowaniem miastenii u matki, dobra odpowiedź terapeutyczna na neostygminę oraz charakterystyczne wspomniane powyżej nieprawidłowości w badaniach elektrofizjologicznych.

Miastenia o podłożu autoimmunologicznym ujawnia się po 6.m.ż, najczęściej około 2 r.ż.

W zdecydowanej większości przypadków jej potwierdzenie stanowi wykrycie przeciwciał przeciw receptorowi dla acetylocholiny w surowicy (postać seropozytywna), choć istnieją pacjenci z rozpoznaną miastenią, u których nie wykrywa się tych markerów immunologicznych (postać seronegatywna).

Wrodzone zespoły miasteniczne stanowią natomiast heterogenną grupę schorzeń uwarunkowanych genetycznie, będących następstwem mutacji genów kodujących białka tworzące struktury presynaptyczne, synaptyczne, postsynaptyczne. Zmienność nasilenia objawów jest zależna od typu mutacji. Pacjenci prezentują objawy tuż po urodzeniu lub w ciągu pierwszych miesięcy życia - najczęściej do 2 r.ż. Może występować artrogrypoza oraz stany przebiegające $\mathrm{z}$ nagłą niewydolnością oddechową spowodowaną bezdechem. Pomocne w prawidłowym zdiagnozowaniu tej 
grupy chorób są: dodatni wywiad rodzinny, brak przeciwciał przeciw receptorowi dla acetylocholiny oraz redukcja amplitudy potencjałów wywołanych powtarzającym bodźcem w badaniu elektrofizjologicznym [12-14].

Zaburzenia transmisji nerwowo-mięśniowej mogą być spowodowane także przez inne sytuacje kliniczne takie jak: zatruciem jadem kiełbasianym (botulizm niemowlęcy) oraz hipermagnezemię.

Choroby mięśni również stanowią ważną przyczynę wiotkości w okresie niemowlęcym i wczesnego dzieciństwa. We wspomnianej powyżej publikacji Laugela [7] pacjenci z miopatiami stanowili obok dzieci z SMA najliczniejszą grupę spośród badanych $z$ hipotonią o charakterze obwodowym (14 spośród 22). Na chorobę związaną z zajęciem mięśni może wskazywać charakterystyczny fenotyp tzw. miopatyczna twarz, wcześnie ujawniająca się niewydolność oddechowa, osłabienie odruchów ścięgnistych oraz przykurcze. Badaniem, które należy wykonać w pierwszej kolejności przy podejrzeniu mięśniowego charakteru wiotkości jest oznaczenie stężenia kinazy kreatyninowej (CK), podwyższony jej poziom obserwuje się we wrodzonych dystrofiach, niektórych postaciach wrodzonych miopatii oraz w miopatiach metabolicznych, jednak prawidłowy poziom nie wyklucza tego podłoża. Na chorobę mięśniową może wskazywać również nieprawidłowy wynik badania EMG. Biopsja mięśnia może być przydatna w identyfikacji wrodzonych dystrofii mięśniowych, wrodzonych miopatii (techniki immunohistochemiczne, mikroskopia elektronowa), miopatii mitochondrialnych (oznaczenie aktywności kompleksów enzymatycznych). Jednak z uwagi na swoją inwazyjność obecnie jest zastępowana coraz częściej diagnostyką genetyczną [6].

Wrodzone dystrofie mięśniowe to grupa chorób dziedziczonych w sposób autosomalnie recesywny, których przebieg kliniczny może być bardzo różnorodny, ale typowa jest znacznego stopnia uogólniona hipotonia i osłabienie siły mięśniowej oraz powolna progresja objawów, stężenie CK może być istotnie podwyższone lub mieścić się w zakresie normy, zapis EMG wskazuje na miogenny typ uszkodzenia- charakterystyczne są bardzo gęsto ułożone potencjały jednostek ruchowych o niskiej amplitudzie i krótkim czasie trwania. Metodę z wyboru do potwierdzenia rozpoznania tej grupy stanowi biopsja mięśnia. W badaniu histopatologicznym uwagę zwracają współistniejące zmiany o charakterze degeneracji i regeneracji włókien mięśniowych oraz zastępowania uszkodzonych włókien tkanką łączną i thuszczową. Badania immunohistochemiczne pozwalają na podział wrodzonych dystrofii mięśniowych na grupę dystrofii merozyno-ujemnych i merozyno-dodatnich.

Do merozyno-ujemnych dystrofii mięśniowych zaliczamy: klasyczną dystrofię mięśniową z deficytem merozyny, dystrofię mięśniową Fukuyamy, zespół Walkera-Warburga, zespół mięsień-oko-mózg. Poza klasyczną wrodzoną dystrofią mięśniową, pozostałe jednostki charakteryzuje zajęcie ośrodkowego układu nerwowego (opóźnienie rozwoju psychoruchowego, niepełnosprawność intelektualna, drgawki, wady takie jak mikrogyria mózgu i móżdżku, wodogłowie, hipomielinizacja szlaków korowo-rdzeniowych) oraz wady narządu wzroku (mikroocze, zaćma, dysplazja siatkówki, zanik nerwu II).

Merozyno-dodatnie dystrofie mięśniowe charakteryzuje łagodniejszy przebieg kliniczny, hipotonia i osłabienie siły mięśniowej mają mniejsze nasilenie, rzadziej dochodzi do rozwoju przykurczów w porównaniu z grupą merozyno-ujemnych dystrofii. Większość pacjentów osiąga umiejętność samodzielnego chodu, rozwój poznawczy jest prawidłowy. Do grupy tej włącza się: dystrofię wrodzoną typu Ulricha oraz Rigid Spine Syndrome.

Wrodzona dystrofia miotoniczna (choroba Steinerta) stanowi jedną z najczęstszych chorób mięśniowych związanych z hipotonią, ujawniających się w okresie noworodkowym i niemowlęcym, dziedziczoną w sposób autosomalnie dominujący, zazwyczaj po matce - występuje u 15-25\% noworodków matek $\mathrm{z}$ dystrofią miotoniczną. W okresie płodowym ruchy płodu są słabe, występuje wielowodzie. Od pierwszych dni życia ujawnia się znacznego stopnia hipotonia, trudności z karmieniem, porażenie mięśni twarzy. Stany zagrażające życiu stanowią: niewydolność oddechowa wymagająca wentylacji mechanicznej, aspiracja treści pokarmowej oraz kardiomiopatia. Rozwój psychoruchowy jest opóźniony, a intelekt poniżej normy. Mimo ciężkiego przebiegu w okresie noworodkowym, większość pacjentów osiąga zdolność do samodzielnego poruszania W wieku późniejszym z uwagi na poprawę funkcji mięśni. W postępowaniu diagnostycznym należy uwzględnić występowanie miotonii (trudność w wykonaniu szybkiego rozkurczu mięśni) u matki zarówno w badaniu klinicznym jak i elekrofizjologicznym oraz wykonanie badań molekularnych oceniających liczbę powtórzeń trójek nukleotydowych CTG $(>1000)$ w genach DMPK oraz SIX5. Zmiany histopatologiczne w wycinku mięśnia są niespecyficzne. Oprócz wrodzonych dystrofii mięśniowych również miopatie wrodzone mogą powodować zespół dziecka wiotkiego, część z nich ujawnia się w okresie niemowlęcym. Do cech, które mogą sugerować to rozpoznanie należą poza hipotonią i osłabieniem siły mięśniowej: ptoza, oftalmoplegia, mikrognatia, wysoko wysklepione podniebienie, deformacje kostne, skolioza. Stężenie CK jest zazwyczaj prawidłowe, rzadziej podwyższone, zapis EMG miogenny. Wykonanie biopsji mięśnia, badań histochemicznych i mikroskopii elektronowej ułatwia postawienie prawidłowego rozpoznania. Na podstawie charakterystyki morfologicznej wyróżniono: miopatię nemalinową, miotubularną, miopatię typu central core, miopatię typu multi-minicore. Obecnie w niektórych spośród nich możliwe jest wykonanie diagnostyki genetycznej $[6,10,15]$.

Choroby mitochondrialne, glikogenozy mięśniowe oraz zaburzenia oksydacji kwasów tłuszczowych mogą przebiegać z zajęciem mięśni. Jednak izolowana miopatia w przebiegu chorób metabolicznych występuje rzadko, częściej obserwuje się postacie z wielonarządową manifestacją, co zostało szczegółowo opisane poniżej.

Na rycinie 1 przedstawiono schemat postępowania diagnostycznego w hipotonii mięśniowej. 
Rycina 1. Schemat

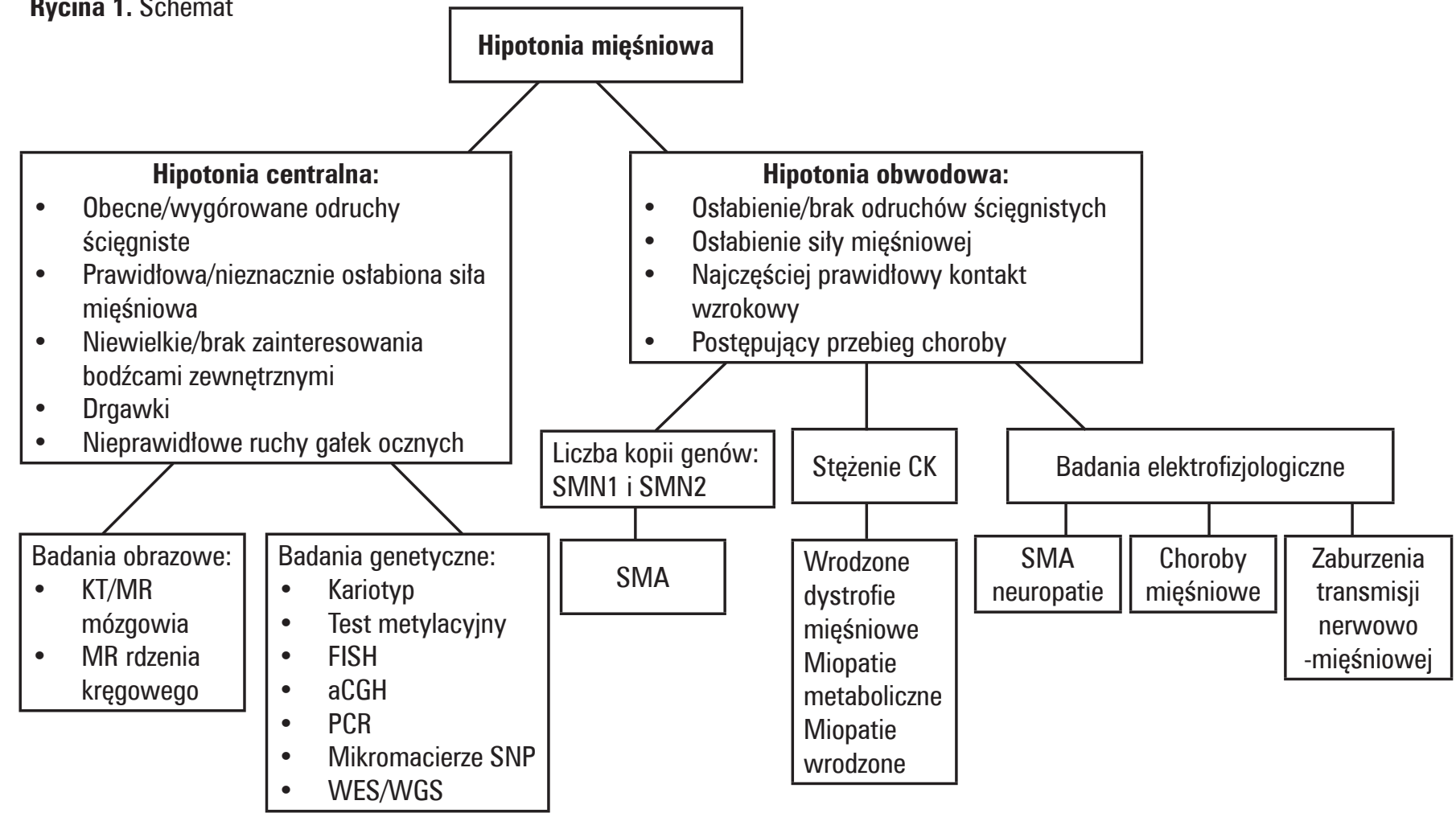

\section{Choroby metaboliczne a zespół dziecka wiotkiego}

W publikacji autorstwa Laugela i wsp. [7], w której przeanalizowano 144 przypadki obniżonego napięcia mięśniowego w okresie niemowlęcym, u 2 pacjentów $\mathrm{z}$ hipotonią o charakterze obwodowym potwierdzono podłoże metaboliczne obserwowanych zaburzeń. Analizując choroby metaboliczne jako przyczynę wiotkości centralnej ujawniono dodatkowo 8 przypadków. Łącznie w całej grupie badanej ujawniono zatem 10 przypadków hipotonii o podłożu metabolicznym, co stanowi niepomijalny odsetek $7 \%$.

W chorobach metabolicznych hipotonia stanowi częsty, aczkolwiek nieswoisty objaw. Może mieć charakter stały lub nasilać się w czasie zaostrzeń. Choć najczęściej wiotkość ma charakter centralny, niewykluczony również jest jej charakter obwodowy i mieszany. Poza zmianami w badaniach obrazowych ośrodkowego układu nerwowego, na hipotonię o podłożu metabolicznym wskazywać może szerokie spektrum współwystępujących objawów klinicznych (tzw. hipotonia plus) takich jak: zmniejszone łaknienie, wymioty, zaburzenia oddychania, nadmierna reakcja na bodźce zewnętrzne, ataksja, zaburzenia świadomości, objawy piramidowe, ruchy choreoatetotyczne, zaćma, zwyrodnienie barwnikowe siatkówki, hepatosplenomegalia, artropatia i wiele innych. Ich wystąpienie obliguje do przeprowadzenia diagnostyki metabolicznej. W ramach tej diagnostyki należy na wstępie wykonać podstawowe badania laboratoryjne takie jak: morfologia, oznaczenie stężenia glukozy, mleczanów, kwasu moczowego, amoniaku. Nieprawidłowości mogą sugerować określone choroby lub grupy zaburzeń metabolicznych, które zostały zestawione w tabeli I.
Następnym etapem jest ocena aminogramu w osoczu i płynie mózgowo-rdzeniowym (w przypadku podejrzenia aminoacydopatii), stężenia kwasów organicznych w moczu (w przypadku podejrzenia acydurii organicznych), acylokarnityn w osoczu (w przypadku podejrzenia zaburzeń oksydacji kwasów thuszczowych, kwasic organicznych), bardzo długich kwasów tłuszczowych w osoczu (w przypadku podejrzenia chorób peroksysomalnych), izoform transferryny (w przypadku wrodzonych zaburzeń glikozylacji).

Tab. I. Odchylenia w badaniach laboratoryjnych w chorobach metabolicznych Abnormalities in laboratory tests in metabolic defects

\begin{tabular}{|c|c|}
\hline $\begin{array}{l}\text { Rodzaj zmian w badaniu } \\
\text { laboratoryjnym: } \\
\text { Type of changes in the } \\
\text { laboratory test: }\end{array}$ & $\begin{array}{l}\text { Grupa zaburzeń } \\
\text { metabolicznych: } \\
\text { Group of metabolic } \\
\text { disorders: }\end{array}$ \\
\hline hiperamonemia & $\begin{array}{c}\text { zaburzenia cyklu } \\
\text { mocznikowego, kwasice } \\
\text { organiczne, zaburzenia } \\
\text { oksydacji kwasów } \\
\text { tłuszczowych }\end{array}$ \\
\hline $\begin{array}{c}\text { podwyższone stężenie } \\
\text { mleczanów }\end{array}$ & choroby mitochondrialne \\
\hline $\begin{array}{l}\text { podwyższone stężenie } \\
\text { 7-dehydrocholesterolu }\end{array}$ & $\begin{array}{c}\text { zespół Smith-Lemliego- } \\
\text { Opitza }\end{array}$ \\
\hline pancytopenia & kwasice organiczne \\
\hline nieprawidłowa glikemia & $\begin{array}{l}\text { glikogenozy, choroby } \\
\text { mitochondrialne }\end{array}$ \\
\hline $\begin{array}{c}\text { podwyższone stężenie } \\
\text { kwasu moczowego }\end{array}$ & zespół Lescha-Nyhana \\
\hline
\end{tabular}


Spośród chorób metabolicznych, w których obraz kliniczny wpisuje się wiotkość na pierwszy plan wysuwają się choroby mitochondrialne. Stanowią one heterogenną grupę ponad 200 jednostek chorobowych o postępującym charakterze. $\mathrm{W}$ ich przebiegu poza zajęciem mięśni szkieletowych co omówiono powyżej dochodzi również do wystąpienia objawów ze strony ośrodkowego układu nerwowego, do których należą: incydenty udaropodobne, encefalopatia, napady padaczkowe, mioklonie, ataksja. Ponadto $\mathrm{w}$ chorobach mitochondrialnych zajęcie mięśnia sercowego manifestuje się jako kardiomiopatia czy zaburzenia rytmu. Również objawy okulistyczne takie jak: zwyrodnienie barwnikowe siatkówki, nieprawidłowe ruchy gałek ocznych, ptoza, oftalmoplegia, zanik nerwów wzrokowych mogą stanowić element obrazu klinicznego chorób mitochondrialnych. Pacjenci z chorobami mitochondrialnymi często prezentują brak przyrostu masy ciała, niewydolność wątroby, zwłaszcza po zastosowaniu kwasu walproinowego oraz cukrzycę. Na rozpoznanie choroby mitochondrialnej poza podwyższonym stężeniem mleczanów, CK oraz miopatycznym zapisem EMG mogą naprowadzać nieprawidłowości w badaniach obrazowych - zajęcie jąder podkorowych w MR głowy w sekwencji T2, nieprawidłowy wynik spektroskopii rezonansowej mięśni- obniżona fosfokreatyna. Najczęstszą chorobę mitochondrialną w populacji pediatrycznej stanowi zespół Leigha. Jest to uwarunkowana genetycznie: autosomalnie recesywnie (mutacje genu SURF), dominująco lub w sprzężeniu z chromosomem X, rzadziej wskutek mutacji genomu mitochondrialnego w nukleotydzie 8993, ciężka, bardzo źle rokująca encefalopatia, w której objawy takie jak: wiotkość, zaburzenia oddychania w postaci napadów hiperwentylacji, bezdechów, oczopląs lub inne nieprawidłowe ruchy gałek ocznych ujawniają się w okresie niemowlęcym.

$\mathrm{Z}$ punktu widzenia klinicysty najważniejsze jest jak najszybsze wykrycie chorób, dla których istnieje skuteczne leczenie. Ważny przykład stanowi choroba Pompego, gdzie z powodzeniem stosuje się enzymatyczną terapię zastępczą- Myozyme (alfaglukozydaza alfa), która spowalnia jej postęp. Choroba Pompego jest dziedziczona autosomalnie recesywnie, wynika z niedoboru enzymu lizosomalnego kwaśnej alfa-maltazy, może ujawnić się w wieku niemowlęcym, dziecięcym, młodzieńczym jak i u dorosłych. Do charakterystycznych objawów klasycznej postaci choroby oprócz narastającej hipotonii rozpoczynającej się około 2. m.ż należą: niewydolność krążenia związana z przerostem mięśnia sercowego i zaburzeniami rytmu serca oraz hepatomegalia. Dodatkowo towarzyszą im: makroglosja, niedosłuch, problemy z karmieniem, nieprawidłowy przyrost masy ciała. Bez leczenia niemowlęta umierają około 9 m.ż. W nieklasycznej postaci tej choroby objawy pojawiają się później, ale najczęściej przed ukończeniem pierwszego roku życia. Pogłębiająca się hipotonia i osłabienie siły mięśniowej prowadzą do zahamowania rozwoju motorycznego. Również występuje kardiomegalia, ale zwykle nie prowadzi do niewydolności serca. Długość życia jest jednak skrócona z powodu postępującej niewydolności oddechowej $[1,16]$.

\section{Choroby tkanki łącznej a zespół dziecka wiotkiego:}

Choroby tkanki łącznej takie jak zespół Ehlersa-Danlosa czy zespół Marfana oraz inne choroby związane z nieprawidłową budową kolagenu VI również w swoim obrazie klinicznym mają wpisaną wiotkość, której towarzyszyć może opóźnienie rozwoju psychoruchowego. Choć obraz kliniczny u najmłodszych pacjentów może przypominać choroby nerwowo-mięśniowe, to w badaniu neurologicznym siła mięśniowa jest prawidłowa, a zakres ruchomości w stawach nadmierny.

Obecnie znanych jest kilkanaście typów zespołu Ehlersa -Danlosa uwarunkowanych mutacjami genów kodujących różne podjednostki kolagenu m.in.: COL 5A1, COL5A2, COL 1A1, COL 3A1. Z kolei zespół Marfana wywołany jest głównie mutacjami genu FBN1 [5].

\section{Wrodzona hipotonia o tagodnym przebiegu (ang. Bening Congenital Hipotonia)}

Pomimo wysiłku diagnostycznego podejmowanego w diagnostyce dziecka wiotkiego nie zawsze można ustalić przyczynę obniżonego napięcia mięśniowego. Wrodzona hipotonia o łagodnym przebiegu stanowi częsty problem w praktyce klinicznej, rozpoznanie to może zostać postawione po wykluczeniu innych przyczyn wiotkości. Charakteryzuje się obniżonym napięciem mięśniowym od urodzenia, ruchy spontaniczne są zachowane, odruchy ścięgniste obecne, rozwój psychoruchowy przebiega prawidłowo lub jest nieznacznie opóźniony. Wyniki badań elektrofizjologicznych, biopsja mięśnia, czy stężenia enzymów mięśniowych mieszczą się w zakresie normy. Charakterystyczne jest występowanie innych przypadków wiotkości $\mathrm{w}$ rodzinie oraz poprawa napięcia w miarę dojrzewania ośrodkowego układu nerwowego. W przyszłości u pacjentów z wrodzoną łagodną hipotonią może dojść do rozwoju hipermobilności w stawach skutkującej ich zwichnięciami. Istotną rolę odgrywa leczenie usprawniające [6].

\section{Podsumowanie:}

Dziecko wiotkie to pacjent, który stanowi wyzwanie diagnostyczne dla lekarzy wielu specjalności m.in. pediatrów, neurologów dziecięcych, metabolistów, genetyków z uwagi na stale wydłużającą się listę jednostek chorobowych związanych z wiotkością. W powyższej pracy podjęto próbę przeanalizowania najczęstszych przyczyn wiotkości, które mogą ujawnić się u najmłodszych dzieci, co może usprawnić ustalenie rozpoznania. Szybkie postawienie diagnozy ma istotne znaczenie z klinicznego punktu widzenia, ponieważ w niektórych jednostkach chorobowych przebiegających z wiotkością możliwe jest zastosowanie leczenia spowalniającego ich przebieg. Omówienie tych chorób przekracza ramy tego opracowania, w którym wspomniano o dwóch spośród nich: SMA i chorobie Pompego. Ponadto rozpoznanie pozwala na ocenę rokowania, a w chorobach uwarunkowanych genetycznie implikuje konieczność objęcia rodziny pacjenta poradnictwem genetycznym. W procesie diagnostycznym na wstępie należy wykluczyć stany związane z hipotonią, które mogą zagrażać życiu takie jak: infekcje uogólnione, neuroinfekcje, 
uraz okołoporodowy, dyselektrolitemię, hipoglikemię, zatrucia lekami, narkotykami przyjmowanymi przez matkę w czasie ciąży - co stanowi główne zadanie pediatry oraz neonatologa.

Szczegółowy wywiad, badanie przedmiotowe pozwalają na dalsze ukierunkowanie procesu diagnostycznego na przyczyny wiotkości o charakterze centralnym (ograniczona reaktywność na bodźce zewnętrzne, drgawki, obecne/ wygórowane odruchy ścięgniste, brak/niewielkie osłabienie siły mięśniowej) lub obwodowym (osłabienie siły mięśniowej, brak odruchów ścięgnistych, cichy płacz, trudności w karmieniu, prawidłowy kontakt wzrokowy).

Proces diagnostyczny w hipotonii centralnej należy rozpocząć od wykonania badań obrazowych ośrodkowego układu nerwowego- MR, ewentualnie KT (uwidocznienie zwapnień charakterystycznych np. dla niektórych infekcji z grupy TORCH) oraz badań genetycznych ( kariotyp, FISH, aCGH, badania molekularne).

W hipotonii obwodowej po wykluczeniu SMA, należy wykonać badania elektrofizjologiczne, oznaczenie poziomu CK oraz w uzasadnionych klinicznie przypadkach biopsję mięśnia lub nerwu obwodowego. Ostateczne rozpoznanie w dużej mierze jest możliwe dzięki badaniom genetycznym.

Zidentyfikowanie przyczyny hipotonii ma szczególne znacznie kliniczne, gdyż po pierwsze w niektórych chorobach istnieją możliwości skutecznego leczenia hamującego ich postęp (np. SMA, choroba Pompego), po drugie wiele z nich jest uwarunkowanych genetycznie co implikuje konieczność poradnictwa genetycznego w rodzinach obciążonych.

\section{PIŚMIENNICTWO}

[1] Szczepanik E., Mierzewska H., Terczyńska I.: Dziecko wiotkie- Floppy Child. [w:] Standardy postępowania diagnostyczno-terapeutycznego w schorzeniach układu nerwowego u dzieci i młodzieży t. 2. Steinborn B. [red.], BiFolium, Lublin, 2015

[2] Prasad AN., Prasad C.: The floppy infant: contribution of genetic and metabolic disorders. Brain Dev 2003; 25: 457-476.

[3] Prasad AN., Prasad C.: Genetic evaluation of the floppy infant. Semin Fetal Neonatal Med 2011;16: 99-108.
[4] Hartley L., Ranjan R.: Evaluation of the floppy infant. Paediatr Child Health 2015; 25: 498-504.

[5] Jędrzejowska M.: Wiotkie dziecko.[w:]:Choroby nerwowo-mięśniowe. Irena Hausmanowa-Petrusewicz [red.], Czelej, Lublin 2013

[6] Bodensteiner JB.: The evaluation of the hypotonic infant. Semin Pediatr Neurol 2008;15: 10-20.

[7] Laugel V., Cossée M., Matis J., et al.: Diagnostic approach to neonatal hypotonia: retrospective study on 144 neonates. Eur J Pediatr 2008; 167: 517-523.

[8.] Jędrzejowska M., Kostera-Pruszczyk A.: Rdzeniowy zanik mięśni- nowe terapie, nowe wyzwania. Neurol Dziec 2017; 26: 11-17.

[9] Jędrzejowska M., Hausmanowa-Petrusewicz I.: Rdzeniowy zanik mięśni. [w:] Choroby nerwowo-mięśniowe. Irena Hausmanowa-Petrusewicz [red.], Czelej, Lublin 2013.

[10] Igarashi M.: Floppy infant syndrome. J Clin Neuromuscul Dis 2004; 6: 69-90.

[11] Kaler J., Hussain A., Patel S., et al.: Neuromuscular Junction Disorders and Floppy Infant Syndrome: A Comprehensive Review Cureus 2020; 12:e6922.

[12] Engel AG., Shen XM., Selcen D., et al.: Congenital myasthenic syndromes: pathogenesis, diagnosis, and treatment. Lancet Neurol 2015; 14: 420434.

[13] Fidziańska A.: Wrodzone zespoły miasteniczne [w:] Choroby nerwowomięśniowe. Irena Hausmanowa-Petrusewicz [red.], Czelej, Lublin 2013.

[14] Fidziańska A.: Wrodzone dystrofie mięśniowe [w:] Choroby nerwowomięśniowe. Irena Hausmanowa-Petrusewicz [red.], Czelej, Lublin 2013.

[15] Fidziańska A.: Miopatie wrodzone [w:] Choroby nerwowo-mięśniowe. Irena Hausmanowa-Petrusewicz [red.], Czelej, Lublin 2013.

[16] Rokicki D.: Dziecko wiotkie- spojrzenie metabolisty. Klinika Pediatryczna 2016; 24: 6034-6040.

Adres do korespondencji:

Paulina Komasińska Katedra i Klinika Neurologii Wieku Rozwojowego Uniwersytet Medyczny im. K. Marcinkowskiego w Poznaniu ul. Przybyszewskiego 49, 60-355 Poznań, paulinakomasinska@interia.pl 